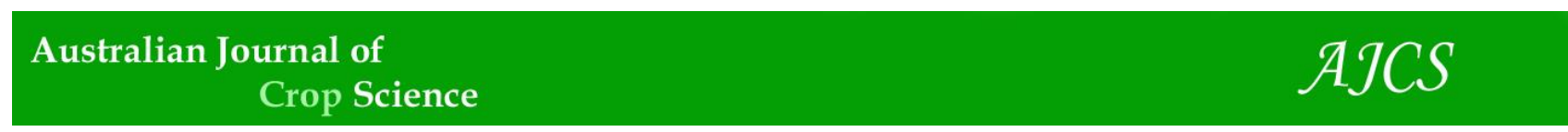

AJCS 11(11):1418-1424 (2017)

ISSN:1835-2707

doi: 10.21475/ajcs.17.11.11.pne541

\title{
Physical properties of soils under different management systems in the Cerrado region of Brazil
}

\author{
Gisele Carneiro da Silva Teixeira ${ }^{1 *}$, Elton Fialho dos Reis ${ }^{1}$, Itamar Rosa Teixeira ${ }^{1}$, Roberto José de \\ Freitas $^{2}$, Fenelon Lourenço de Sousa Santos ${ }^{2}$
}

${ }^{1}$ State University of Goiás, Campus of Anápolis, 75132-400, Anápolis-GO, Brazil
${ }^{2}$ State University of Goiás, Campus of Ipameri, 75780-000, Ipameri-GO, Brazil

*Corresponding author: gisele.agronomia@ hotmail.com

\begin{abstract}
The physical properties of a soil can be influenced by management systems, but information on the effects of management systems such as integrated crop-livestock-woods is still incipient and inconclusive. Therefore, this study aimed to evaluate the changes in the physical attributes of Cerrado soil under different management systems. Soil samples were collected and subjected to an experiment with a completely randomized, $5 \times 3$ factorial design with five replications. The treatments were different management systems (notillage, integrated livestock-woods, cultivated pasture, degraded pasture and preserved area - reference), and samples were collected from three soil depths $(0-10,10-20$ and $20-30 \mathrm{~cm})$. The following physical soil characteristics were evaluated: density, total porosity and resistance to penetration. Additionally, the organic matter content has previously been determined for the different systems under analysis. The results showed that soils under conservation management involving corn and integrated crop-livestock-woods presented greater soil density but were also less susceptible to compaction, especially the superficial soil layer. The resistance of the soil profile to penetration was lower under conservation management compared to pasture (cultivated or degraded), but it was superior to that of the reference soil. The areas under braquiária ruziziensis pasture or degraded with Urochloa decumbens pasture presented higher resistance to soil penetration.
\end{abstract}

Keywords: Physical properties; Conservation systems; Integrated crop-livestock-woods; Soil management.

Abbreviations: iCLW_integrated crop-livestock-woods, ICL_integrated crop-livestock systems, CE_Cerrado areas, PF_Pinus caribeae forest, PA_pasture, TI_no-tillage, TOC_total organic carbon, Sd_soil density, Tp_total porosity.

\section{Introduction}

Soil conservation management systems, such as iCLW, that do not continuously rotate distinct species in the same area achieve better soil quality (Silva, 2008; Balbino et al., 2011). Therefore, the contribution of the decomposing vegetable biomass generated by these systems is more important than the physical complexity of the soil.

The major aim of iCLW is the revitalization of degraded pasture areas in the Mid-West region of Brazil and the incorporation of these areas into the production process, avoiding the pressure from livestock observed in new productive areas at lower latitudes, such as the Amazon (Vilela et al., 2011). However, information on the impacts of iCLW on soil quality, especially the physical properties, remains scarce.

Recent researches on this topic, which are limited by the short time since the implementation of these systems, have generated contradictory results. For example, Assis et al. (2015) aimed to determine the alterations in the physical features of the 0-0.10- and 0.10-0.20-m layers of Cerrado soil under iCLW, that is, iLPF1 and iLPF3, respectively; the results allowed the authors to conclude that the iCLW systems enhanced the physical quality of the soil relative to degraded pasture. Patterns of density and porosity in the $0.10-$ $0.20-\mathrm{m}$ soil layer were mainly responsible for discriminating the integrated systems from degraded pasture. Similarly,
Souza Neto et al. (2014) evaluated the physical properties and organic carbon content of haplorthox soil under the integrated crop-livestock-woods system in the Cerrado of Mato Grosso do Sul-Brazil and found that all pasture treatments increased soil density and resistance to penetration and decreased the total and macro porosity compared to VN. Soil density (1.8-1.47 $\mathrm{Mg} \mathrm{m}^{-3}$ ), macro porosity $\left(0.14-0.17 \mathrm{~m}^{3}\right.$ $\left.\mathrm{m}^{-3}\right)$ and resistance to penetration values $(0.62-0.81 \mathrm{MPa})$ at the depth of $0-10 \mathrm{~cm}$ were smaller compared to those of VN $\left(17.6 \mathrm{Mg} \mathrm{ha}^{-1}\right)$.

Because they are dynamic, iCLW conservation systems require continuous scientific and technological research, which is almost always conducted through long-term and regional-scale experiments. Without this effort, these systems would not be sustainable, which would make it difficult for farmers to adopt them. Many lines of research, as well as technology transfer and promotion, need to be strengthened so that knowledge and information can be increased when conservation systems are adopted as a sustainable choice. Overall, agricultural research must be conducted in an integrated way and reflect the reality of production systems so that the generated technologies are transferred more efficiently with less of a time lag. This way, information on the effects of deploying integrated conservation systems on soil's physical (density, porosity, resistance to penetration, 
moisture dynamics and retention, etc.) and chemical (organic matter content) properties will be more readily available to researchers, technicians and producers to support decision making about proper soil management.

Thus, this study aimed to investigate the changes in the physical features of Cerrado soil under different conservation management systems in areas where implementation has been underway for less than 10 years.

\section{Results and Discussion}

\section{Soil density}

The results of the analysis of variance showed that the physical features of the soils evaluated in this study were separately influenced by factors related to the harvest system and the sampling depths, except for particle density, which was solely influenced by the harvest systems. An effect of the interaction of the factors on the evaluated physical soil properties was not detected (Table 1). In general, the collected data exhibited good experimental precision; the coefficients of variation ranged from 3.9 to 14.4 following the criteria established by Pimentel-Gomes (1990).

Soil density was higher in areas whose soils were initially disturbed due to the application of techniques such as subsoiling, scarification, plowing and drilling. In contrast, systems whose soils did not suffer disturbance during preparation, that is, degraded pasture and the preserved area, presented lower soil density values (Table 1 ). This variation certainly occurred due to the application of soil preparation techniques prior to sowing because there was a compaction problem in the superficial soil layers even after ten years of experimental implementation, which was likely promoted by farm equipment traffic during the various phases of crop production.

Increased soil density exacerbates problems related to compaction, structure and total porosity, which restrict plant growth and development. Therefore, it is necessary to find alternatives to solve problems related to the density of the superficial soil layer during harvest with the aim of increasing productivity.

The highest density values were observed in the subsuperficial soil layers, that is, depths from 10 to $30 \mathrm{~cm}$ (Table $2)$, than in the superficial layer $(0-10 \mathrm{~cm})$, independent of the studied harvest system. This result can be explained by the higher root density in these layers, the high amount of organic matter generated by the decomposition of the remains of the vegetation, and the faunal activity and the weight of the soil itself, whose density increases with depth. These results corroborate those of Reinert et al. (2008) regarding red ultisol under no-tillage cultivation and those of Genro Junior et al. (2004) in highly clayey haplorthox.

The amplitude of soil density within the average limits presents the following variation: 1.00 to $1.25 \mathrm{~g} \mathrm{~cm}^{-3}$ in clayey soils, 1.25 to $1.40 \mathrm{~g} \mathrm{~cm}^{-3}$ in sandy soils, 0.75 to $1.00 \mathrm{~g} \mathrm{~cm}^{-3}$ in composted soils, and 0.20 to $0.40 \mathrm{~g} \mathrm{~cm}^{-3}$ in turfy soils. Thus, the texture of the soils in the sampled areas is sandy-clayey, but sandy soils predominate in areas subjected to more intensive handling.

\section{Particle density}

Particle density differed among in the different studied management systems. Higher values were observed in the areas with cultivated pasture and corn under no-tillage, but lower values were observed in the preserved area and the area with eucalyptus integrated with pasture. Particle density values did not differ among the sampling depths (Table 2). The particle density of the soil varied little, generally presenting values from 2.3 to $2.9 \mathrm{~g} \mathrm{~cm}^{-3}$ with an average of $2.7 \mathrm{~g} \mathrm{~cm}^{-3}$, and it was basically influenced by the main constituent minerals in the soils: quartz, feldspar and silicate, which present an average particle density of $2.7 \mathrm{~g} \mathrm{~cm}^{-3}$. The particle density of tropical and subtropical soils is approximately $3.0 \mathrm{~g} \mathrm{~cm}^{-3}$ (Hillel, 2013), and the average particle density values in the sampled areas varied from 2.4 to 2.7, which were within the reference values mentioned above.

\section{Total porosity}

The total porosity varied among the soil management systems, with higher values in preserved areas and degraded pasture, that is, in areas that were not intensively exploited over the years. These results were opposite the results observed for soil density, which was higher in intensively managed areas (Table 2).

Total porosity differed with sampling depth independent of the management system with higher values in the surface soil, that is, the $0-10-\mathrm{cm}$ layer, but it did not differ significantly from the value obtained for the intermediate layer $(10-20 \mathrm{~cm})$, partially agreeing with the density results, in which higher values were observed in deeper soil layers. It is noteworthy that these results are consistent with the literature (Souza et al., 2005); total porosity decreases with an increase in density, which commonly increases with soil depth.

\section{Organic matter and organic carbon}

The results for the contents of organic matter and organic carbon were similar, especially for areas with cultivated pasture and preserved areas, which presented higher values. In contrast, the area with integrated eucalyptus plantation and pasture presented the lowest organic matter content and accumulated soil organic carbon (Table 2).

The incorporation of $\mathrm{CO}_{2}$ during photosynthesis via $\mathrm{C} 4$ metabolism is associated with high plant biomass production, which was exhibited by the predominant forage grasses in the cultivated pasture system, and this higher soil organic matter and organic carbon contents. In the preserved area, the higher organic matter and organic carbon accumulation rate were explained by the higher accumulation of decomposing vegetation in the superficial soil layer of the soil, or the plant litter (Magalhães et al., 2009), which mainly consists of leaves in forest systems.

The organic matter and organic carbon contents varied with sampling depth, but higher values were found in the superficial soil layer due to the accumulation of decomposing vegetation at this site, which was independent of the soil management system. These results partly agree with those obtained by Santos and Tomm (2013), who attempted to determine the availability of nutrients and organic matter content under different harvest and soil management systems in Passo Fundo-RS, Brazil and found higher organic matter values in the 0-5-cm layer compared to the 15-20-cm layer in all of the management systems (no no-tillage, minimum notillage, conventional soil preparation with a plow and disc harrows and conventional soil preparation with a moldboard plow and disc harrows) and harvest systems (system I: wheat/soy; system II: wheat/soy and peas ca/corn; and system III: wheat/soy, peas ca/corn and white oat/soy). Similar results were observed with respect to the higher availability of organic matter in the surface soil, that is, the $0-5-\mathrm{cm}$ layer, 
Table 1. Summary of the analysis of variance of the physical properties of soils at different sampling depths under different management systems in the Cerrado region of Brazil.

\begin{tabular}{lcccccc}
\hline Treatments & G.L. & \multicolumn{5}{c}{ Average squares - AS } \\
\cline { 3 - 6 } & & DS & DP & PT & MO & CAR \\
\hline Systems (S) & 4 & $0.2206^{* *}$ & $0.2628^{* *}$ & $148.6139^{* *}$ & $496.9800^{* *}$ & $167.1841^{* *}$ \\
Depth (D) & 2 & $0.0333^{* *}$ & $0.0199^{\text {ns }}$ & $98.0484^{* *}$ & $519.8933^{* *}$ & $174.8921^{* *}$ \\
S x P & 8 & $0.0104^{\text {ns }}$ & $0.0048^{\text {ns }}$ & $9.5912^{\text {ns }}$ & $23.7100^{\text {ns }}$ & $7.9760^{\text {ns }}$ \\
Residue & 60 & 0.0062 & 0.0103 & 17.3709 & 13.6200 & 4.5818 \\
\hline C.V. (\%) & - & 5.4 & 3.9 & 9.5 & 14.4 & 14.4 \\
\hline C. & & &
\end{tabular}

GL: liberty grade; SD: soil density; PD: particle density; TP: total porosity; OM: organic matter; CAR - carbon; CV - coefficient of variation.

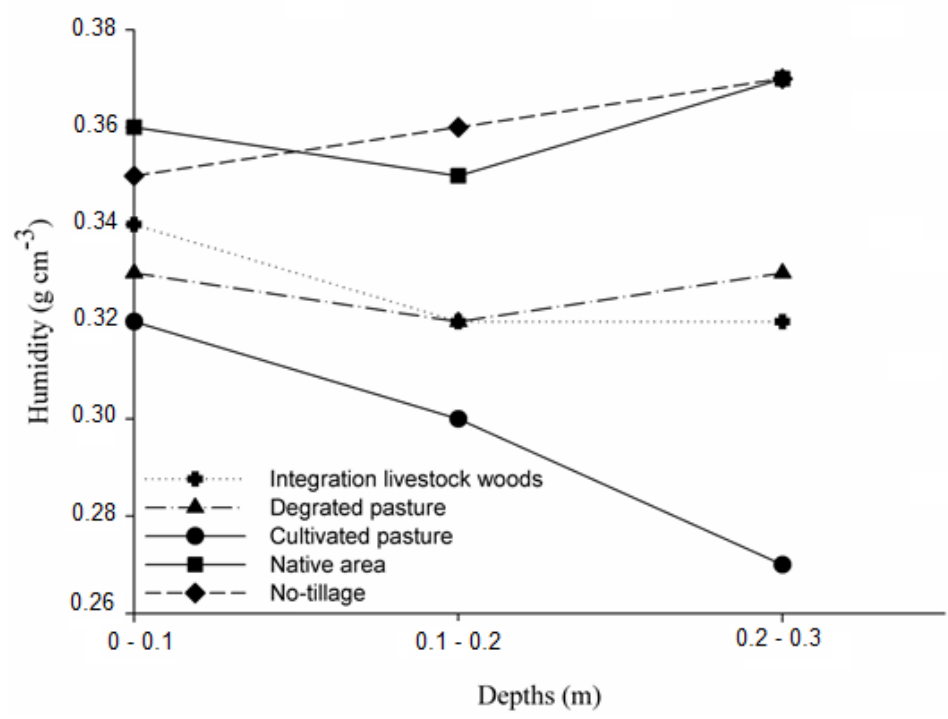

Fig 1. Soil gravimetric humidity under different soil management systems at three sampling depths (0-0.1, 0.1-0.2 and 0.2-0.3 m) in the Cerrado region of Brazil.

Table 2. The average values of the soil physical properties at different sampling depths under different management systems in the Cerrado region of Brazil.

\begin{tabular}{|c|c|c|c|c|c|}
\hline \multirow[b]{2}{*}{ Treatments } & \multicolumn{5}{|c|}{ Physical Properties of the Soil } \\
\hline & $\begin{array}{l}\text { Soil Density } \\
\left(\mathrm{g} \mathrm{cm}^{-3}\right)\end{array}$ & $\begin{array}{l}\text { Particle Density } \\
\left(\mathrm{g} \mathrm{cm}^{-3}\right)\end{array}$ & $\begin{array}{l}\text { Total Porosity } \\
(\%)\end{array}$ & $\begin{array}{l}\text { Organic matter } \\
\left(\mathrm{g} \mathrm{dm}^{-3}\right)\end{array}$ & $\begin{array}{l}\text { Carbon } \\
\left(\mathrm{g} \mathrm{dm}^{-3}\right)\end{array}$ \\
\hline \multicolumn{6}{|l|}{ Management systems } \\
\hline No-tillage & $1.53 \mathrm{a}$ & $2.66 \mathrm{ab}$ & $42.48 \mathrm{bc}$ & $21.40 \mathrm{bc}$ & $12.41 \mathrm{bc}$ \\
\hline Integration livestock-woods & $1.55 \mathrm{a}$ & $2.56 \mathrm{c}$ & $39.37 \mathrm{c}$ & $19.00 \mathrm{c}$ & $11.02 \mathrm{c}$ \\
\hline Cultivated pasture & $1.54 \mathrm{a}$ & $2.71 \mathrm{a}$ & $43.27 \mathrm{bc}$ & $29.47 \mathrm{a}$ & $17.09 \mathrm{a}$ \\
\hline Degraded pasture & $1.34 \mathrm{~b}$ & $2.60 \mathrm{bc}$ & $47.73 \mathrm{a}$ & $24.80 \mathrm{~b}$ & $14.38 \mathrm{~b}$ \\
\hline Preserved area (witness) & $1.29 \mathrm{~b}$ & $2.37 \mathrm{~d}$ & $45.40 \mathrm{ab}$ & $33.07 \mathrm{a}$ & $19.18 \mathrm{a}$ \\
\hline Mean & 1.45 & 2.58 & 43.65 & 25.55 & 14.82 \\
\hline DMS & 1.45 & 0.10 & 4.28 & 3.79 & 1.46 \\
\hline \multicolumn{6}{|l|}{ Sample depth (cm) } \\
\hline $0-10$ & $1.41 \mathrm{~b}$ & - & $45.57 \mathrm{a}$ & $30.08 \mathrm{a}$ & $17.45 \mathrm{a}$ \\
\hline $10-20$ & $1.45 \mathrm{ab}$ & - & $43.77 \mathrm{ab}$ & $25.60 \mathrm{~b}$ & $14.85 \mathrm{~b}$ \\
\hline $20-30$ & $1.49 \mathrm{a}$ & - & $41.62 \mathrm{~b}$ & $20.96 \mathrm{c}$ & $12.16 \mathrm{c}$ \\
\hline Mean & 1.45 & - & 43.65 & 25.54 & 14.82 \\
\hline DMS & 0.05 & - & 2.83 & 2.51 & 1.46 \\
\hline
\end{tabular}

Values followed by different letters in the same column are significantly different according to Tukey's test at a $5 \%$ level of probability. DMS: significant difference. 

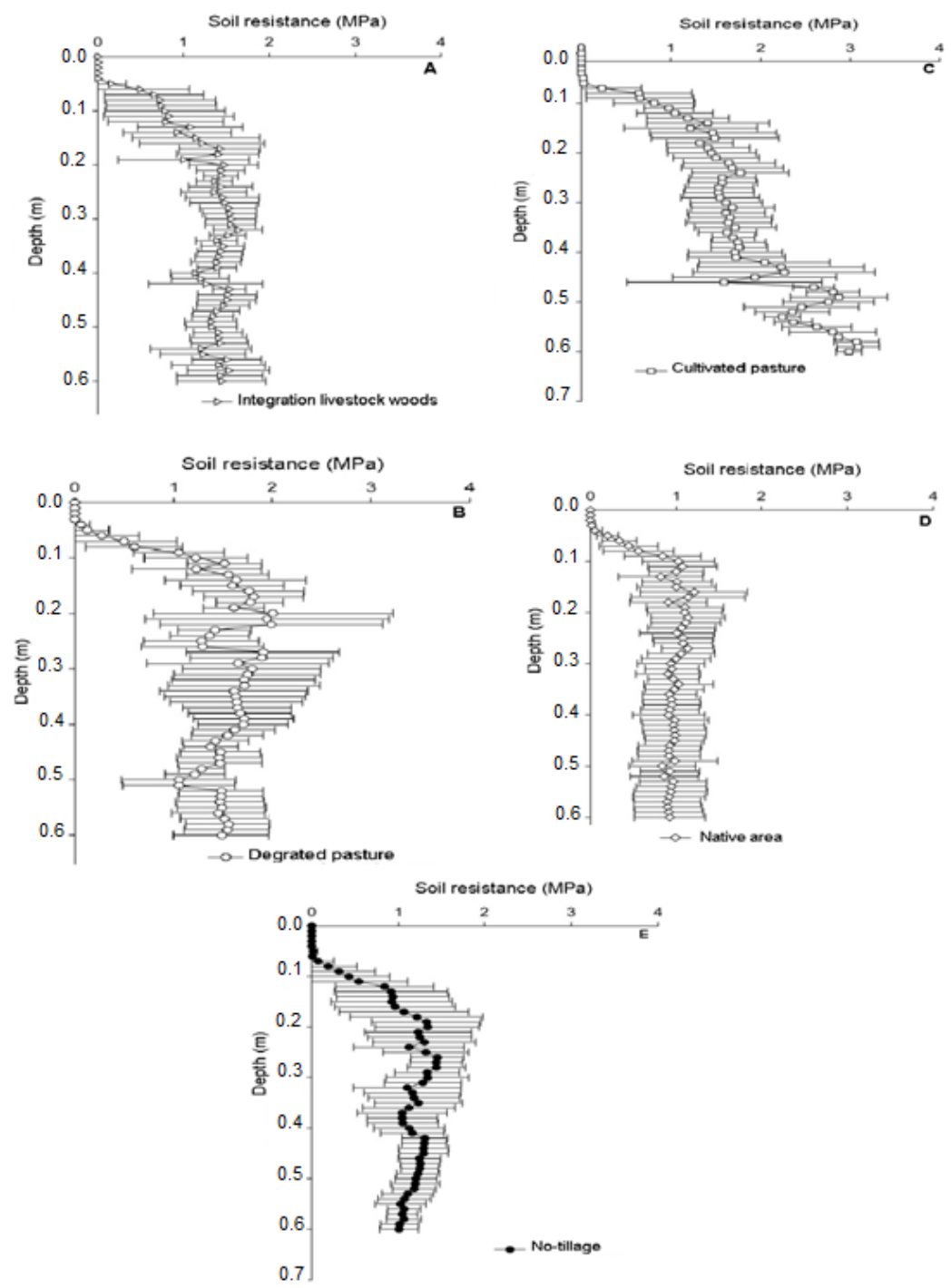

Fig 2. Soil resistance to penetration under different management systems at depths from 0-0.6 $\mathrm{m}$ in the Cerrado region of Brazil.

compared to the soil at a depth of $10-20 \mathrm{~cm}$; these results were obtained by Ensinas et al. (2016), who studied organic matter fractions in haplorthox in Cerrado conditions under a no-tillage rotation system involving cover crops: fall-winter corn, fall-winter corn intercropped with $U$. ruziziensis, fallwinter corn intercropped with $U$. ruziziensis, U. brizantha $\mathrm{cv}$. Marandu, Pennisetum glaucum L. and a reference area (native vegetation).

\section{Resistance of the soil to penetration}

Penetration resistance can predict whether roots will have difficulty penetrating the soil, so quantifying it is an important indicator of the growth and development dynamics of plant radicular systems. However, soil humidity is strictly related to root penetration, so it is essential for determining the water content of the soil while analyzing its resistance to penetration. At the depths of 0-10 10-20 and 20-30 cm, soil moisture was homogeneously distributed throughout the profile, reaching values close to field capacity under the five tested soil management systems and corroborating the results of studies by Serafim (2008) and Silveira et al. (2010). Thus, it was not feasible to determine differences in penetration resistance in relations to soil humidity at the time of sampling (Figures 1 and 2).

For the $0-60-\mathrm{cm}$ soil layer, resistance to penetration was higher in pasture soils compared to the other studied systems, both cultivated and degraded, especially in the $20-\mathrm{cm}$ subsuperficial soil layer (Figures 2B,C). In this situation, the maximum values varied from $3.3 \mathrm{MPa}$ for degraded pasture to $3.7 \mathrm{MPa}$ for cultivated pasture, which were greater than the values from the literature that are considered critical for root development, 2.5 MPa (Canache, 1990) and 3.0 Mpa (Koolen e Kuippers, 1983). This problem is due to alterations to the physical properties of the soil, such as density and total porosity, which can be related to trampling by animals. Muller et al. (2001) and Moreira et al. (2005) found similar soil compaction results related to forces applied to the soil surface, that is, animal cargo under intensive or extensive management regimes, and they found that soil compaction significantly affects the development of the radicular system of grass pasture, such as "braquiarinha", which consequently lowers the production of the aerial part.

When one compares the resistance penetration values observed in the $0-20-\mathrm{cm}$ layer, which is considered to be farmable and is where most of the radicular system is located, it is noteworthy that the compaction problem generally 
already begins to manifest at the depth of $20 \mathrm{~cm}$ in pasture areas, either cultivated or not, in comparison to the wooded area (reference). The formation of compacted areas decreases the biological activity and macro porosity of the soil profile and increases soil density, which promotes greater physical resistance to radicular expansion (Souza et al., 2005; Jimenez et al., 2008). Additionally, it limits soil permeability and nutrient and water availability (Freddi et al., 2007). Moreover, management and previous stressors alter soil aggregation, texture, water content, and organic matter (Llanillo et al., 2006). Therefore, if soil is maintained in its natural state; it presents physical features, such as density, porosity, aggregation and permeability that are considered adequate (Andreola et al., 2000).

In contrast, the preserved area (reference) (Figure 2d), which is also referred to as native woods and represented non-anthropic soil in this study, presented the lowest penetration resistance values, which did not reach levels that inhibit root development, throughout the sampled soil profile compared to the other systems. The lower penetration resistance observed in the preserved area can be explained by the presence of organic matter throughout the soil profile (Table 1), which is especially due to the accumulation of plant litter on the soil surface that is associated with higher soil humidity (Freitas et al., 2010). Soil structure is another factor that contributes to lower resistance to penetration in the preserved area because it allows for better connectivity between soil components, which leads to lower density (Azevedo e Sverzut, 2007).

Cultivated areas involving the integration of eucalyptus and pasture and no-tillage corn (Figures 2A, E) presented lower penetration resistance throughout the sampled soil profile in pasture (cultivated and degraded), with the highest value being 2.0 $\mathrm{MPa}$ in both situations, which is below the critical value for plant root development. In the farmable soil layer, that is, $0-20 \mathrm{~cm}$ deep, it is possible to observe values close to 1.5 and 1.2 $\mathrm{MPa}$ for integrated eucalyptus and pasture and no-tillage corn, respectively, showing that even in "disturbed" systems like these subjected to animal traffic and even with minimal soil preparation and machinery traffic, soil penetration resistance has not increased. When the soil penetration resistance values of these areas were compared to those of the reference area (preserved area), the values for the conservation areas were lower than those of the preserved area throughout the soil profile, never surpassing the values for root development.

The soil penetration resistance results observed for areas under conservation systems in relation to systems that promote less soil disturbance, such as pastures, partly contrast with the soil density results. The greater resistance values in the no-tillage corn and eucalyptus plus pasture systems were not very different from those for cultivated pasture (Table 2), so the conservation systems should have presented greater problems related to soil penetration. These results also contrast with the information in the literature that soils under intensive management, such as conservation systems like no-tillage, frequently exhibit problems related to the compaction of the superficial layers, which are promoted by variations in the natural soil arrangement and by pressure from farm equipment during the seeding, fertilizer application, spraying and harvest phases (Ralisch et al., 2007). The same results were observed in pastures associated with extensive cattle production, mainly on clayey soils with high levels of moisture.

However, based on the results of this study, it can be concluded that the densification of the soil profile under conservation systems (Table 2), that is, no-tillage corn and the integrated woods-livestock system (currently eucalyptus plus pasture), was insufficient to promote an increase in soil resistance to critical levels. In addition, the adoption of efficient soil management techniques in the aforementioned systems, such as continuously maintaining trash over the soil, controlling the number of animal units in the pasture area, reducing machinery traffic in harvest areas, and avoiding the use of machinery on humid soil, among others, reduced the problem of compaction in the areas under cultivation.

\section{Materials and Methods}

\section{Research site}

The study was conducted on October 16, 2006 in a private experimental area in Fazenda Santa Brígida, which is in Ipameri in the southeast region of the state of Goias $\left(17^{\circ} 39^{\prime} 27^{\prime \prime} \mathrm{S} ; 48^{\circ} 12^{\prime} 22 \mathrm{~W}\right)$ at $800 \mathrm{~m}$ above sea level. This study area was chosen because it houses the first experimental field for investigating the integrated iCLW system in Brazil.

According to the Köppen classification, the local climate is Cwa, which is mesothermal tropical savanna with welldefined seasons: a rainy period from October to April and a dry period from May to September. The annual average rainfall in the region is $1.447 \mathrm{~mm}$ with an average temperature of $21.9^{\circ} \mathrm{C}$.

Most of the soil on the property is classified as haplorthox, which is of acid origin with naturally low fertility and welldrained with a clay-sandy texture (approximately $45 \%$ clay) (Embrapa, 2006); these are the predominant characteristics of most soils in the Brazilian Cerrado region. The topography of the area is plain to slightly sloped, but there are some sites where the relief is more rugged.

\section{Experimental design and treatments}

Soil samples were subjected to an experiment with a $5 \times 3$ factorial, completely randomized design with three replications. The treatments consisted of different soil management systems (no-tillage, integrated livestock-woods, cultivated pasture, degraded pasture and preserved area reference), and samples were collected from three depths (0$10,10-20$ and $20-30 \mathrm{~cm}$ ).

No-tillage: This area was previously continuous cultivated under a succession/rotation system of soy, corn and sorghum crops under tenancy, but it has been under no-tillage for more than eight years, undergoing an interchange between soy and corn crops with braquiária ruziziensis trash (Urochloa ruziziensis) applied between harvest and the second crop. During sampling, corn, cv. simple Syngenta Impacto ${ }^{\circledR}$ (recommended material for the region) in the seed-growing phase was planted at a distance of $0.5 \mathrm{~m}$ under dried braquiária ruziziensis trash with the remains of the previous soy crop at a density of 62.000 plants $\mathrm{ha}^{-1}$.

Integrated livestock-woods: This management treatment was implemented in 2006, but the area was initially under crops such as soy or corn intercropped with braquiária brizantha cv. Marandu (Urochloa brizantha). After the soy or corn harvest, pasture was cultivated with the aim of feeding cattle during Cerrado droughts; at the beginning of the rainy period, the area was dried to yield trash for no-tillage agriculture with soy intercropped with braquiária brizantha to achieve practically the same objective as mentioned above. In the third year of no-tillage, that is, 2009, the forest component was introduced to the area with eucalyptus var. Citriodora at a spacing of $26 \mathrm{~m}$ between double lines ( $3 \times 1$ 
between each plant) at a density of 1.667 trees $\mathrm{ha}^{-1}$; the interline spaces remained occupied by braquiária ruziziensis intercropped with dwarf pigeon pea. At the time of sampling, the area was stocked with "nelore" calves in the fattening phase for meat production at a stocking rate of $1.1 \mathrm{AU} \mathrm{ha}^{-1}$. Cultivated pasture: Ten years ago, rotating pasture with braquiária ruziziensis was implemented; there is no grass cropping under rotation/succession with this type of management. At the time of soil sampling, there was a population of "nelore" cattle bred for meat production at a stocking rate of $4.5 \mathrm{AU} \mathrm{ha}^{-1}$ with the offer of constant feed. Degraded pasture: This area has a rugged aspect (slopes greater than 5\%) with braquiária pasture (Urochloa decumbens) in a stage of advanced degradation. The stocking rate of the "nelore" population for meat production at the time of sampling was $1.0 \mathrm{AU} \mathrm{ha}{ }^{-1}$. Preserved area (reference): This area consisted of 27 hectares under permanent preservation (PPA) with original Cerrado vegetation, in the strict sense, dominated by large trees such as peppertree, sucupira (Pterodon emarginatus), trumpet tree, and courbaril, among others. There was a thick layer of litter on the soil surface that was approximately four centimeters thick. This area was taken as a reference because it presents an undisturbed pedological profile.

\section{Sample collection}

The different areas were sampled on May 20, 2015. The treatment (handling systems) and reference (area with an undisturbed pedological profile) samples were collected from five equidistant locations, and afterwards, simple, deformed samples were taken with a Dutch piercer to analyze texture analysis and organic matter content at depths of 0-10, 10-20 and $20-30 \mathrm{~cm}$. Undisturbed samples were taken at the same depths to analyze soil density and total porosity.

\section{Physical and chemical analyses}

The following physical features of the soil were analyzed for each treatment: soil and particle density, total porosity, the contents of organic matter and organic carbon and the resistance of the soil to penetration. The particle density (Pd) was determined by the volumetric flask method. Soil density (Sd) was calculated as the dry mass of the soil in a hothouse, and total porosity (Tp) was determined from the soil and particle density (Embrapa, 2005). The organic matter analysis was performed using the colorimetric method with sodium dichromate. The resistance of the soil to penetration was determined by electronic penetrograph with a rod penetration speed of $30 \mathrm{~mm} \mathrm{~s}^{-1}$. A cone pointer with a diameter of 12.83 $\mathrm{mm}$ and a $30^{\circ}$ penetration angle was used for the analysis. The equipment resolution was $7.7 \mathrm{kPa}$, and the maximum cone index was $7.700 \mathrm{kPa}$ (ASABE, 2006).

\section{Statistical analysis}

The data were subjected to analysis of variance by an F test, and when suitable, Tukey's test was applied at a 5\% level of probability to determine the possible effects of the tested treatments. The Statistical Analysis and Genetics (SAEG) program was used for data analysis.

\section{Conclusion}

Soils under conservation management, that is, that involving no-tillage corn and the integration of woods and pasture, presented higher soil density, but they were less susceptible to compaction, mostly in the superficial soil layer.
The soil resistance to penetration profile under conservation management was lower in relation to the pasture areas (cultivated or degraded), but it was greater that of the reference soil from the woods. Areas under cultivation and degraded pastures presented higher soil resistance to penetration values. The use of efficient soil management techniques in the cropping system, such as applying continuous layers of straw in the soil, controlling the number of bovine units on pasture, reducing of machine traffic in cropping areas, and avoiding the use of machinery on wet soil, among others, contributed to the lack of soil compaction in the cultivated areas.

\section{Acknowledgements}

The first author thanks to the State University of Goias/ Campus Anápolis, the realization to perform the posdoctorate study whose research activities originated this article. We also thanked Coordination for the Improvement of Higher Education Personnel (CAPES) for granting scholarship."

\section{References}

Andreola F, Costa LM, Olszevski, N (2000) Influência da cobertura vegetal de inverno e da adubação orgânica e, ou, mineral sobre as propriedades físicas de uma terra roxa estruturada. Rev Bras Cienc Solo 24: 857-865.

ASABE (2006) American Society of Agricultural and Biological Engineers. Soil cone penetrometer. ASAE Standard S313.2. St. Joseph, p. 903-904.

Assis PCR, Stone LF, Medeiros JC, Madari BE, Oliveira JM, Wruck FJ (2015) Atributos físicos do solo em sistemas de integração lavoura-pecuária-floresta. Eng Agrí Ambient 19: 309-316.

Azevedo EC, Sverzut CB (2007) Alterações dos atributos físicos e químicos do solo sob pastagem no sudoeste do estado de Mato Grosso. Rev Agropecu Trop. 9: 7-23.

Balbino LC, Cordeiro LAM, Porfirio da Silva V, Moraes A, Martínez GB, Alvarenga RC, Kichel AN, Fontaneli RS, Santos HP, Franchini JC, Galerani PR (2011) Evolução tecnológica e arranjos produtivos de sistemas de integração lavoura-pecuária-floresta no Brasil. Pesqui Agropecu Bras. 46: 1-12.

Cunha JPAR, Carvalho Júnior PC, Souza JV, Borges EN, Reis EF (2009) Compactação do solo sob sistemas de manejo convencionais e conservacionistas. Eng Agríc 17: 155-162.

Embrapa (2005) Empresa Brasileira de Pesquisa Agropecuária Manual de laboratórios: Solo, água, nutrição vegetal, nutrição animal e alimentos. São Carlos, Embrapa Pecuária Sudeste, 334p.

Ensinas SC, Serra AP, Marchetti ME, Silva EF, Prado EAF, Lourente ERP, Altomar PH, Potrich DC, Martinez MA, Conrad VA, Jesus MV, El Kadri TC (2016) Cover crops effects on soil organic matter fractions under no till system. Aust J Crop Sci. 10: 503-512.

Freddi OS, Centurion JF, Beutler AN, Aratani RG, Leonel CL (2007) Compactação do solo no crescimento radicular e produtividade da cultura do milho. Rev Bras Cienc Solo. 31: 627-636.

Freitas ECS, Oliveira Neto SN, Fonseca DM, Santos MV, Machado VD (2010) Deposição de serapilheira e de nutrientes no solo em sistema agrossilvipastoril com eucalipto e acácia. Rev Arvore. 37: 409-417. 
Genro Junior SA, Reinert DJ, Reichert JM (2004) Variabilidade temporal da resistência à penetração de um Latossolo argiloso sob semeadura direta com rotação de culturas. Rev Bras Cienc Solo. 28: 477-484.

Hillel D (2013) Fundamentals of soil physics. Academic Press, Inc., New York, N.Y, USA, 413p.

Jimenez RL, Gonçalves WG, Araújo Filho JV, Assis RL, Pires FR, Silva GP (2008) Crescimento de plantas de cobertura sob diferentes níveis de compactação em um Latossolo Vermelho. Eng Agríc Ambient. 12: 116-121.

Koolen AJ, Kuipers, H (1983) Agricultural soil mechanics. Germany: Springer-Verlag, 242p.

Llanillo RF, Richart A, Filho JT, Guimarães MF, Ferreira RRM (2006) Evolução de propriedades físicas do solo em função dos sistemas de manejo em culturas anuais. SeminCienc Agrar 27: 205-220.

Magalhães WA, Cremon C, Mapeli NC, Silva WN, Carvalho JM, Mota MS (2009) Determinação da resistência do solo a penetração sob diferentes sistemas de cultivo em um Latossolo sob bioma Pantanal. Agrarian. 2: 21-32.

Moreira JAV, Oliveira IP, Guimarães CM, Stone LF (2005) Atributos químicos físicos de um latossolo vermelho distrófico sob pastagens recuperada e degradada. Pesq Agropecu Trop. 35: 155-161.

Muller MML, Guimarães MF, Desjardins T, Martins PFS (2001) Degradação das pastagens na Região Amazônica: propriedades físicas do solo e crescimento das raízes. Pesqui Agropecu Bras. 36: 1409-1418.

Pimentel-Gomes F (1990). Curso de estatística experimental. 13.ed. Piracicaba: Nobel. 468p.

Ralisch R, Miranda TM, Okumura RS, Barbosa GMC, Guimarães MF, Scopel E, Balbino LC (2007) Resistência a penetração de um latossolo vermelho amarelo do cerrado sob diferentes sistemas de manejo. Eng Agríc Ambient. 12: 381-384.
Reinert DJ, Albuquerque JA, Meichert JM, Aita C, Andrada, MCC (2008) Limites críticos de densidade do solo para o crescimento de raízes de plantas de cobertura em argissolo vermelho. Rev Bras Cienc Solo. 32: 805-1816.

Richart A, Tavares Filho J, Brito OR, Llanillo RF, Ferreira R (2005) Compactação do solo: causas e efeitos. Semin-Cienc Agrar 26: 321-344.

Santos HP, Tomm GO (2003) Disponibilidade de nutrientes e teor de matéria orgânica em função de sistemas de cultivo e de manejo de solo. Cienc Rural. 33: 447-486.

Serafim ME, Vitorino ACT, Peixoto PPP, Souza CMA, Carvalho DF (2008) Intervalo hídrico ótimo em um latossolo vermelho distroférrico sob diferentes sistemas de produção. Eng Agríc. 28: 654-665.

Silveira DC, Melo Filho JF, Sacramento JAAS, Silveira, ECP (2010) Relação umidade versus resistência à penetração para um Argissolo Amarelo distrocoeso no recôncavo da Bahia. Rev Bras Cienc Solo. 34: 659-667.

Sousa Neto EL, Andrioli I, Almeida RG, Macedon MCM, Lal R. (2014) Physical quality of an oxisol under in integrated crop-livestock-forest system in the brazilian cerrado. Rev Bras Cienc Solo. 38: 608-618.

Souza ED, Carneiro MAC, Paulino HB (2005) Atributos físicos de um Neossolo Quartzarênico e um Latossolo Vermelho sob diferentes sistemas de manejo. Pesqui Agropecu Bras. 40: 1135-1139.

Vilela L, Martha Junior GB, Macedo MCM, Marchão RL, Guimarães Júnior R, Pulrolnik K, Maciel GA (2011). Sistemas de integração lavoura-pecuária na região do Cerrado. Pesqui Agropecu Bras. 46: 1127-1138.

Wendling B, Vinhal-Freitas IC, Oliveira RC, Babata MM, Nascentes EM (2012) Densidade, agregação e porosidade do solo em áreas de conversão do cerrado em floresta de pinus, pastagem e plantio direto. Biosci J. 28: 256-265. 